\title{
China, The World Trade Organization, And The Market For Rare Earth Minerals
}

\author{
Joseph A. Giacalone, Ph.D., St. John's University - NY, USA \\ Genai Greenidge, MS, St. John's University - NY, USA
}

\begin{abstract}
Rare earth elements (also referred to as rare earth minerals, rare earth metals, green elements, rare earths or simply REEs) are comprised of 17 elements of the periodic table. The metals are often found combined together in ores and must be separated into its individual elements. On the supply side of the market, China is currently the largest producer of rare earth elements in the world, mining at least $90 \%$ of total world production. Consequently, many countries around the world rely on imports of these REEs to facilitate production of the various systems and products that are dependent on the rare earth metals as raw materials. With one supplier effectively monopolizing the rare earth industry, this imposes severe supply-chain risks to the producers of products that rely on rare earth minerals. After several actions that have restricted the supply, the United States, the European Union, and Japan have challenged China for violating provisions of its membership in the World Trade Organization. This paper will examine the rare earth industry, China's near-monopoly, global supply-chain risks, and strategies to reduce dependence on China, including the invocation of the WTO's dispute resolution process.
\end{abstract}

Keywords: Rare Earth Minerals; Rare Earth Elements; Rare Earth Metals

\section{INTRODUCTION}

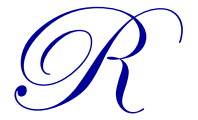

are earth elements (also referred to as rare earth minerals, rare earth metals, green elements, rare earths or simply REEs) are comprised of 17 elements of the periodic table which include 15 elements from the group known as lanthanides and two additional elements known as scandium and yttrium. The metals are often found combined together in ores and must be separated into its individual elements.

\section{THE DEMAND SIDE OF THE MARKET}

The various applications of rare earth elements are numerous and can be broadly classified into four major categories, namely: High Technology Consumer Products, Environmentally Friendly Products, Industrial and Medical Devices and National Defence Systems. In the United States, estimated data through the first eight months of 2011 showed the distribution of rare earths by end use as follows: chemical catalysts for automotive and petroleum refining, 47\%; metallurgical applications and alloys, 13\%; alloys, 11\%; glass polishing and ceramics, 10\%; permanent magnets for electric and hybrid vehicles, $9 \%$; ceramics, 5\%; phosphors for computer monitors, lighting, radar TVs, and x-ray intensifying film, 5\%. (USGS 2012). The demand for such high technology products is steadily increasing in both the US and globally, causing an upsurge in the derived demand for rare earth metals. For an overview of the rare earths market, see Giacalone (2012).

\section{CHINA'S CURRENT NEAR-MONOPOLY ON THE SUPPLY SIDE OF THE MARKET}

At present China is the largest producer of Rare Earth elements in the world, mining, by various estimates, at least $90 \%$ of total world production. Consequently, many countries, including the United States and Japan, rely on imports of these REEs from China to facilitate production of the various systems and products that are reliant on rare earths as raw material. For example, Japan relies on imports from China to produce the rechargeable batteries used to power the hybrid vehicles and several other products that it exports to the United States and other countries. It is not unreasonable to assume that a contraction in the global supply of rare earth minerals can adversely affect Japan. 
China has managed to capitalize on the rare earth element industry by developing the resources (technology, techniques and an experienced labor force) required to efficiently and effectively mine, extract, separate and refine rare earth minerals at more operationally feasible costs than other countries. As a result, it became more economically viable for countries, such as the United States, to cease production of rare earth minerals and import these minerals from China. This operational efficiency has caused China to effectively emerge as the leading supplier of rare earth minerals to an extent that could be easily equated to a monopoly. The fact that China controls the global supply of rare earth metal allows the country to effectively control quality, quantity and ultimately the prices of these rare earth elements through export quotas and trade tariffs.

Rare earth elements are not as rare as the name implies. They are reasonably abundant in the earth's crust, even more so than other familiar metals like gold, iron or copper. Thus, the fact that China mines virtually all of total global production is not an indication that the majority of rare earth elements are located in that part of world. As a matter of fact, from as early as 1953 , the United States was a major producer of rare earth elements before suspending operations at its 55 acre mine at Mountain Pass located in California in 1998 (Jenkins, 2010). The United States has become almost fully reliant on China, importing $79 \%$ of it rare earth materials in 2011. Though this is down from $92 \%$ in 2010, it still gives China the upper hand in this market (USGS, Mineral Commodity Summaries, 2012.)

\section{SUPPLY CHAIN RISKS}

\section{The Dependability of the Supplier}

There are several supply chain risks inherent in a global market whereby the supply of virtually all of a raw material (that is rare earth elements) deemed critical to the development of many products that boosts a nation's GDP is largely controlled by one supplier, in this case, China. At present, "both production of rare earth materials in China and export of those materials outside of China are strictly controlled by government imposed quotas" (Molycorp Minerals, 2009). Japan, a country that manufactures and exports many of the parts that use rare earth metals, was exposed to and negatively impacted by one such risk. In September 2010, China placed what seemed to be an unannounced and unofficial embargo on the export of rare earth metals to Japan - a claim that was repeatedly denied by the Chinese government (Humphries, 2010). The incident was initially thought to be related to longstanding maritime wars between the two countries but was heightened when China subsequently began halting exports to other countries as well. This embargo has led many governments around the world to question China's reliability as a supplier of the critical rare earth minerals and has fuelled the urgency of several nations to curtail China's monopoly on the rare earth metal industry.

The contraction of the supply of rare earth materials by China is neither a new nor shocking issue. Margaret Hunt (2010) in her article entitled Rare Earth Dearth states that "experts have been warning of the dangers of U.S. reliance on Chinese rare earths for many years" (p.2). This assertion came subsequent to announcements of decreases in exports of rare earth minerals by Chinese officials. To further exacerbate the concerns of many nations, approximately three months before the apparent embargo placed on Japan, China imposed export restrictions on rare earths that resulted in a supply shortage for countries outside of China. In July 2010, "China announced that it will cut exports this year of rare-earth elements (REE) by $40 \%$, leaving demand outside China exceeding the supply for the first time ever" (Service, 2010a).

\section{Resource Constraints}

Although China produces and refines more than $90 \%$ of the global rare earth metal supply, the reserves outside of China are estimated at least $50 \%$ of the 110 million tons. World reserves refer to the amount of rare earth minerals in the earth's surface that can be economically extracted from mines if the requisite resources and materials were made available to do so. Table 1 below shows the recent data on reserves quantities for various countries. From this table we observe that those countries such as India, Australia and even the United States each have millions of tons of rare earth resources available, presumably enough to satisfy each country's own demand. 
It can be argued that there are sufficient world reserves to meet the forecasted increases in consumption for the foreseeable future (Hedrick \& Cordier, 2010). However, the wealth of rare earth mineral reserves does not seem to be enough to mitigate the current state of crisis regarding an impending supply shortage surging through most countries which rely on rare earth inputs. This is because no matter how abundant world reserves are, without the necessary infrastructure resources to extract the raw materials from the ground and with continued reliance on a China as the dominant source of supply, production will neither be able to meet nor sustain anticipated future demand.

Table 1

World Mine Production And Reserves

(Data in metric tons of rare-earth oxide (REO) content)

\begin{tabular}{|c|c|c|c|}
\hline & \multicolumn{2}{|c|}{ Mine production $^{\mathrm{e}}$} & \multirow[t]{2}{*}{ Reserves $^{1}$} \\
\hline & 2010 & $\underline{2011}$ & \\
\hline United States & - & - & $13,000,000(2)$ \\
\hline Australia & - & - & $1,600,000$ \\
\hline Brazil & 550 & 550 & 48,000 \\
\hline China & 130,000 & 130,000 & $55,000,000$ \\
\hline Commonwealth of Independent States & NA & NA & $19,000,000$ \\
\hline India & 2,800 & 3,000 & $3,100,000$ \\
\hline Malaysia & 30 & 30 & 30,000 \\
\hline Other countries & NA & NA & $22,000,000$ \\
\hline World total (rounded) & 133,000 & 130,000 & $110,000,000$ \\
\hline
\end{tabular}

Source: US Geological Service (2012). Minerals Commodity Summaries 2012. Washington: United States Government Printing Office, 129.

${ }^{\mathrm{e}}$ Estimated. NA Not available. W Withheld to avoid disclosing company proprietary data. — Zero.

${ }^{1}$ That part of the reserve base which could be economically extracted or produced at the time of determination. The term reserves need not signify that extraction facilities are in place and operative. Reserves include only recoverable materials.

(2) It should be noted that Molycorp Inc. accounts for substantially all of the U.S. reserves and in April of this year, it announced a $36 \%$ increase in its proven reserves to over 18 million tons.

\section{Why Would China Restrict Supply?}

There are several possible explanations for why China would be inclined to restrict exports to other countries. The most evident reason is that as China's demand for rare earth dependent technologies such as cell phones, computers, and flat panel displays screens increase, the country's own demand for rare earth elements is quickly outgrowing its supply. Therefore, imposed export restrictions may not be a malicious attempt by the Chinese government to "starve the world of rare earth metals" (Jenkins, 2010), but may be considered necessary to make the metals more readily available for domestic consumption.

Another explanation for reducing export quotas is the country's possible attempt to stimulate its own economy by increasing domestic production of those products like rechargeable batteries and flat panel screens that are currently dominated by other countries such as Japan and India. Therefore, imposing such restriction on supply inevitably increases the company's competitive advantage for sale of these products. This theory was reinforced by Eggert (2010), professor and director of the Division of Economics and Business at the Colorado School of Mines, who argues that "when China restricts exports of a primary raw material, such as rare-earth elements, it presumably is doing so to create an advantage for those manufacturing industries that use rare earths domestically in goods that will be sold both domestically and internationally" (p. 56).

China, itself, argues that it is attempting to bring order to a chaotic and environmentally hazardous industry. By consolidating some mining operations, closing some others, and imposing stringent environmental regulations on mining and processing, supply reductions can be expected. 


\section{RISK MITIGATION STRATEGIES}

Many countries, including the United States, are readily responding to the increasing demand for and contracting supply of rare earth metals. Eggert (2010) suggests that "users of elements for which there are supply risks have a number of options...they can maintain stockpiles, diversify sources of supply, develop joint-sharing arrangements with other users, or develop tighter relations or strategic partnerships with producers" (p.53). Also, more efficient recycling of rare earth materials can assist in curbing the current shortage.

\section{Recycling of Rare Earth Components}

Since rare earth metals are used in a wide variety of products that are upgraded on a continuous basis, the opportunity to extract them from the discarded items presents itself (Tabuchi 2010). Labelled "urban mining," this recycling allows nations with no significant rare earth mining operations to displace some of its imports and reduce some of the supply chain risks. Japan has taken major steps in this direction. After Japanese mining of rare earth elements succumbed to the China's dominance, the country has launched a major initiative to recycle the rare earth metals from the tons of laptops, cell phones, and other products which use them. Japan even imports these used electronics for recycling. Estimates are that used electronics contain as much as 300,000 metric tons of rare earth metals. However, since most of these products contain very small quantities of these metals, the extraction process is complicated and expensive. Yet, it provides some relief from the supply chain risks of total dependence on China. As other countries have recognized the value of these used electronics, they have embraced recycling as an alternate supply source of rare earth metals. China has imposed an export ban on computer mother boards, for example. Recycling efforts in the United States are minimal, mainly permanent magnet scrap.

\section{Stockpile Accumulation}

Another strategy proposed by several experts to cover supply shortages is the accumulation of stockpiles of rare earth oxides. Generating stockpiles is particularly important as a means of meeting military demand for national defense and executing the environmental initiatives of the United States government (Humpries, 2010). According to the United States Geological Survey, there are currently no government stockpiles of rare earth metals (USGS, 2012). Retaining no stockpile of rare earths critical to so many high tech defense mechanisms poses a severe risk to the United States military arsenal.

\section{Supply Chain Diversification}

Though estimates vary, it has been noted above that there are considerable deposits of rare earths are outside of China. Even though diversifying the supply chain has several limitations, countries have recognized that tapping into their own reserves may be a necessary strategy to satiate growing demand and to counteract the risks of further supply restrictions. There are ongoing plans to set up additional production facilities at rare earth mines located in countries like India, South Africa and Canada, and arrangements are being made to resume production of the mines located in Mountain Pass, California and Mount Weld, Australia.

Molycorp Minerals LLC has re-opened a separations plant at its Mountain Pass rare earth deposit. The company is conducting research which is expected to allow this production facility to obtain up to $60 \%$ recovery of rare earth metals from its ore--almost $30 \%$ greater than the current recovery rate currently achieved by China (Jenkins, 2010). However, Jenkins argues that the mine's annual output may not be sufficient to bridge the gap left by reduced Chinese exports. This is especially true for the "heavy" rare earths, such as dysprosium and terbium, which are critical ingredients for the magnets that operate at high temperatures in motors and turbines. The Molycorp deposits are richest in the "light" rare earth elements that work best in low-temperature applications. In any case, Molycorp has entered an agreement to supply rare earths to Japan's Hitachi Metals, one of the world's leading producers of magnets for applications such as missile guidance systems, hybrid automobiles, and electrical wind turbines (Dove, 2011). Hitachi will have to look elsewhere for its requisite "heavy" rare earth metals (Bourzac 2011). 
The rare earth deposits of Australia's Mount Weld are expected to be a significant new source of supply. Owned by the Lynas Corporation, the deposits are considered some of the world's richest. In August, 2011, Lynas opened the first phase of a three-phase development that is expected to eventually produce over 33,000 metric tons annually. Lynas is involved in a joint venture with Siemens, a major player in the market for powerful magnetic devices (Dove, 2011). Lynas has also completed the world's largest rare earth processing plant in Malaysia that will process ores shipped from Australia. Though the plant's opening has been delayed due to protests relating to radiation levels and disposal of waste, Lynas recently obtained a two-year license to begin operations. However, activists vow to continue their fight to stop the plant and have even made it an issue in next year's presidential election. So, although the success of Lynas mining and processing operations would provide a significant challenge to China's dominance, there are still major environmental and political hurdles to overcome (Murdoch 2012).

Brazil is another country with reserves of rare earth elements though largely in an undeveloped state. The giant Japanese firm, Mitsubishi, and Neo Material, a Canadian firm, are evaluating the Brazilian deposits which are estimated at around 20,000 metric tons (D'Atorio 2010). Other potential supply sources include Kazakhstan, Vietnam, and India.

\section{Alternatives to Rare Earth Minerals}

Research to find acceptable alternatives to rare earth metals is still in the early stage. This research is unlikely to develop practical material alternatives in the short-run, if ever. Driving the search for alternatives is the high prices of rare earth materials which had been rising steadily for several years. Another factor has been the conservation of these costly materials by changing production techniques so as to use lesser quantities. Furthermore, the high prices have spurred research into the development of alternative technologies that do not rely heavily or at all on rare earth materials (Bradsher 2011).

Though the prices of rare earths seem to have peaked in June of 2011 and fallen sharply throughout the second half of the year, they remain significantly above what they were just a few years ago. This was due in part to the weak global economy which impacted demand. It was also due to China loosening of its export restrictions. Certainly, high prices for key materials will push the search for cheaper substitutes and technologies. And additional supplies will exert downward pressure on prices. The net effect of these market forces will be determined over the coming years.

\section{The Limitations of Supply Diversification}

As was discussed earlier, one way to reduce the supply risks associated with the current rare earth metal industry is to diversify production outside of China. However, there are several limitations associated with supply diversification in this industry.

The same reasons that most countries opted to rely on imports from China in the first place may prove to be the identical reasons that may make it economically impractical to expand production facilities globally - that is, the low cost of operations that currently exists in China. Eggert (2010) acknowledged this likelihood when he pointed out that "the biggest impediment to the opening of rare-earth mines outside of China is the reality that China is and likely will remain the low-cost producer of rare earths worldwide and probably could supply most world demand at prices lower than those necessary to justify new mines" (p. 53).

In addition, it would be difficult for other countries to secure the necessary expertise in the form of chemical engineers in the short period of time required to meet increasing demand. Karl A. Gschneidner Jr., senior metallurgist and one of the world's leading rare-earth experts, told Congressional panellists in March 2010 that "rare-earth research in the United States on mineral extraction, rare earth separation, processing of the oxides into metallic alloys and other useful forms, substitution, and recycling is virtually zero" (Ingebretsen, 2010). This "shortage of talent" as Ingebretson calls it, could severely undermine attempts by the United States and other countries to diversify production and reduce the monopolistic control of the industry by China. 
Another constraint on diversification is the need to build or re-build the infrastructure needed for mining and processing rare earth elements. When companies moved their operations to China, they abandoned their existing facilities. New entrants to the industry will have to construct facilities from scratch (Bourzac 2011).

In general, getting the required permits to open or expand rare earth production facilities is a lengthy process, from 4-7 years, in most countries. This is because rare earth mining and processing generates toxic, radioactive residue. Environmental concerns tend to dominate the permitting regulations.

\section{Legislative Initiatives}

In the United States, some argue that government should bear much of the responsibility for facilitating the development of domestic production that would reduce the country's reliance on Chinese imports. The process of mining, extracting and separating rare earth elements efficiently and effectively may require the financial aid of government to stimulate research and development initiatives.

In the United States, for example, several bills designed to promote domestic production have been proposed. The U.S. Magnet Materials Association and industry groups representing primarily the mining, aerospace, and defense have lobbied for such legislation. Among them have been The Rare Earths and Critical Materials Revitalization Act of 2010 which supports research and development; the Rare Earths Supply-Chain Technology and Resources Transformation Act of 2010 that facilitates domestic production; and the Fiscal Year 2011 National Defense Authorization Act that incorporates governmental strategy for ensuring long term availability of those rare earth metals critical to national defense as well as sourcing means to reduce the dependency of military weapons on rare earth materials (Humphries, 2010, pgs. 10-12). Most recently, in July 2012, the House of Representatives passed H.R.4402, The National Strategic and Critical Minerals Production Act. However, Senate passage and White House support has not yet materialized.

\section{WORLD TRADE ORGANIZATION DISPUTE RESOLUTION}

Faced with the difficulties and risks in diversifying the rare earth supply chain, the United States, Japan, and the European Union formally accused China in March 2012 of violating the provisions of the WTO with respect to trade in the rare earth minerals. Essentially, China was accused of placing export restrictions on the supply of rare earth and related minerals such as tungsten and molybdenum. Specific restrictions include export quotas, export duties, restrictions on the right to export, and various cost-raising administrative limitations. China dominates the mining of these minerals which are critical to the production of many important products, including sophisticated military technology. The challengers assert that China is trying to extend its dominance beyond mining and into the manufacturing of products with rare earth content. China counter-argues that its export controls are driven largely by environmental concerns, conservation of natural resources, and the pursuit of sustainable development. The consequences, according to the complainants, are supply shortages and higher input prices than would be the case if markets were open. China, it is claimed, reaps an unfair competitive advantage over foreign competition by these trade restrictions. Allegedly, it is not following the trade rules it agreed to when it joined the WTO. (Various sources)

These political entities can and did call for the initiation of the WTO's dispute resolution process handled by its Dispute Settlement Body (DSB). The admitted aim of the process is to settle the dispute and not pass judgment. The process encourages bilateral or multilateral consultation to reach agreement before any formal proceedings are begun. This consultation stage normally lasts up to 60 days. If a settlement is not reached, a panel can be appointed. The defendant country can block the creation of the panel one time but, if no settlement is reached, the Dispute Settlement Body can reconvene and appoint a panel. This part of the process has a 45-day time limit. The appointed panel normally has six months to make its rulings and recommendations. Other steps in the process and the right to appeal typically can extend the overall process from 12 to 15 months.

In the current rare earth case against China, the consultation period ended without agreement and the complainants requested the Dispute Settlement Body to appoint a panel to investigate the matter. As expected, China blocked the creation of this panel. The DSB re-convened in late July 2012, and as per WTO rules, it appointed a 
panel and China cannot block its action. A quick resolution of the dispute is not anticipated since the investigation is likely to be intense and appeals are highly probable.

Some US politicians and pundits have little faith in the WTO dispute resolution process which is likely to be extremely time-consuming and enmeshed in bureaucratic procedures. Some argue for more aggressive action. At least one US Senator has called for blocking Chinese funded mining projects in the US as well as World Bank financing of Chinese mining projects elsewhere. (Areddy and Reddy 2012).

\section{THE MARKET SOLUTION}

Can market forces resolve the trade issue before the WTO can take any meaningful action? There are more than a few who believe that they can (Worstall 2012). As described above, production outside of China is being ramped up in several countries. Previously closed mines and processing operations are being reopened and new ones are being developed. The competitive initiatives provided by the marketplace seem to be intensifying. However, in the short-run, China still has considerable market leverage. Undoing that leverage will take some time and it is unlikely that the WTO can do much about it.

\section{AUTHOR INFORMATION}

Joseph A. Giacalone, Ph.D., is Professor of Economics and Holder of the Henry George Chair in Economics, St. John's University, USA. Dr. Giacalone earned his B.A. and Ph.D. at Columbia University and his MBA at St. John's University. He previously served fifteen years as Associate Dean and four years as Dean of the College of Business Administration. His publications are in the areas of health care economics, business and economic history, economic thought, industry studies, and collegiate business education. E-mail: giacaloj@stjohns.edu (Corresponding author)

Genai Greenidge, MS earned her BBA from Howard University and her MS from St. John's University. At St. John's, she served as research assistant to Professor Giacalone and is currently employed as an Information Technology Business Analyst with ICF International in Fairfax, Virginia. E-mail: gngreenidge@ gmail.com

\section{REFERENCES}

1. Arreddy, James T. and Reddy, Sudeep (2012). Trade Fight Flares on China Minerals. March 13, WSJ.com.

2. $\quad$ Bourzac, Katherine (2011). The Rare Earth Crisis. Technology Review. May-June, 58-63.

3. Bradsher, Keith (2011a). China Consolidates Grip on Rare Earths. September 16. Retrieved from NYTimes.com http://www.mytimes.com/2011/09/16/business/global/china-consolidates-control-of-rareearths

4. Bradsher, Keith (2011b). Prices of Rare Earth Metals are Declining sharply. November 16. Retrieved from NYTimes.com.

5. Bradsher, Keith (2012). Rare Earth Metal refinery Nears Approval, January 21. Retrieved from NYTimes.com.

6. D'Altorio, Tony (2010). Investing in Rare Earth Elements as China's Exports Decline. Retrieved October 17, 2011 at http://www.investmentu.com/2010/October/investing-in-rare-earth-elements.html

7. Dove, Justin (2011). A New Trend in Rare Earth Elements. Retrieved October 17, 2011at http://www.investmentu.com/2011/August/a-new-rare-earth-element-trend.html

8. $\quad$ Eggert, R. G. (2010). Critical Minerals and Emerging Technologies. Issues in Science and Technology, 5356. Retrieved from Academic Search Premier database.

9. Fessler, David (2011). China's Rare Earth Monopoly: The End is Coming, February 11. Retrieved October 17, 2011 at http:/www.investmentu.com/2011/February/china-rare-earth-element-monopoly-ending

10. Giacalone, Joseph A. (2012). The Market for the 'Not-So-Rare' Rare Earth Elements, Journal of International Energy Policy. Spring, Volume 1 Number 1, 11-18, http://www.cluteinstitute.com/

11. Hendrick, J. B., \& Cordier, D. J. (2010). 2008 Minerals Yearbook: Rare Earths. U.S. Department of Interior, U.S. Geological Survey http://minerals.usgs.gov/minerals/pubs/commodity/rare_earths/myb12008-raree.pdf 
12. Hendrick, J. B., \& DiFrancesco, C. A. (2009). Rare Earths Statistics. U.S. Geological Survey: http://minerals.usgs.gov/ds/2005/140/

13. Humphries, M. (2010, September 30). Rare Earth Elements: The Global Supply. Retrieved November 5, 2010, from Federation of American Scientists: http://fas.org/sgp/crs/natsec/R41347.pdf

14. Hunt, M. W. (2010). Rare Earth Dearth. Advanced Materials and Processes, 2. Retrieved from Academic Search Premier database.

15. Ingebretsen, M. (2010). The Global Rare-Earth Race. Advanced Materials and Processes , 24. Retrieved from Academic Search Premier database.

16. Jenkins, S. (2010). Rare-Earth Metals for the Future. Chemical Engineering , 17-18,20,22-23. Retrieved from ABI/INFORM Global. (Document ID: 2181276671)

17. Molycorp, Inc . (2009). Global Outlook. Retrieved November 5, 2010, from Molycorp Minerals: The Rare Earth Company: http://www.molycorp.com/globaloutlook.asp

18. Molycorp, Inc. (2012). Molycorp Rare Earth Reserves at Mountain Pass increase 36\%. April 10. Retrieved from Molycorp.com.

19. Murdoch, Lindsey (2012). First Weld War Looms-Malaysians Mobilize to Fight Lynas Plant, September 13, Retrieved from smh.com.au.

20. Service, R. F. (2010a). Chinese Policies Could Pinch U.S. Efforts to Make Electric Vehicles. Science, 329 (5990), 377. Retrieved from Academic Search Premier database.

21. Service, R. F. (2010b). Nations Move to Head Off Shortages of Rare Earths. Science, 327, 1596-1597. Retrieved from Academic Search Premier database.

22. Tabuchi, Hiroko (2010). Japan Recycles Minerals from Used Electronics, October 4. Retrieved from NYTimes.com.

23. United States Department of Energy (2010). Critical Materials Strategy, December.

24. United States Geological Survey, Minerals Commodity Summaries 2011.

25. United States Geological Survey, Minerals Commodity Summaries 2012.

26. World Trade Organization, Various sources.

27. Worstall, Tim (2012). WTO Acts Over Chinese Rare Earth Restrictions: Late and Irrelevant as Usual. Forbes, July 25. 